\title{
Information and Communication Technology in Event Management
}

\author{
Christine Van Winkle and Jill Bueddefeld
}

\section{Contents}

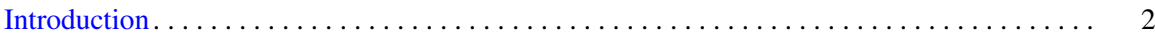

Information and Communication Technologies and the Domains of Event Management . . . 3

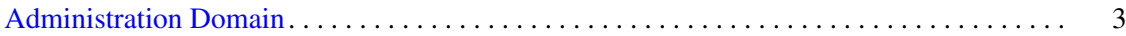

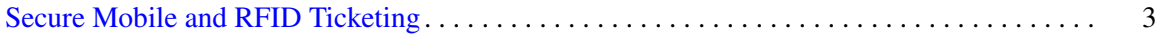

Secure Virtual Payment Methods ................................ 4

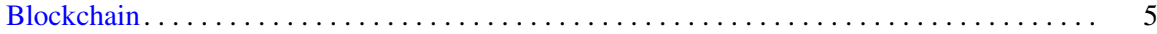

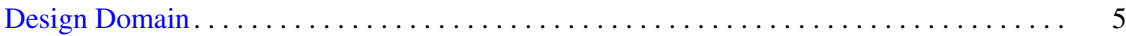

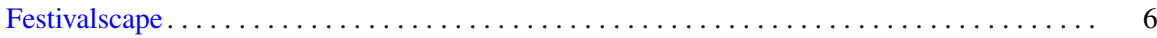

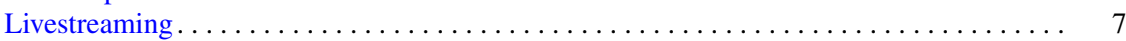

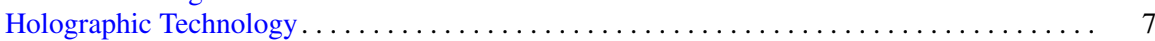

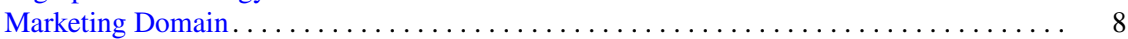

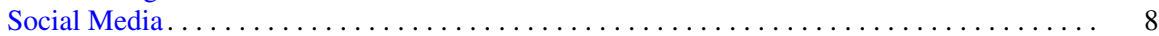

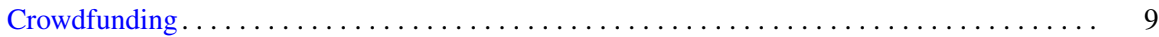

Operations Domain ......................................... 9

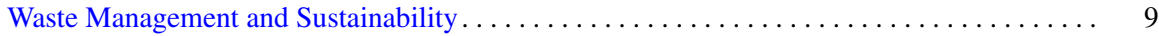

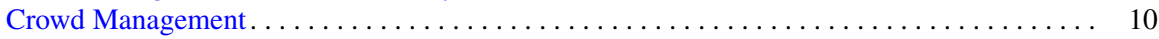

Risk Domain . . . . . . . . . . 10

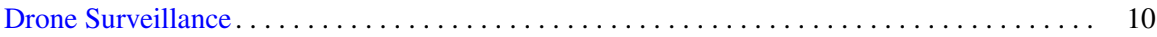

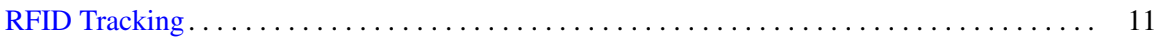

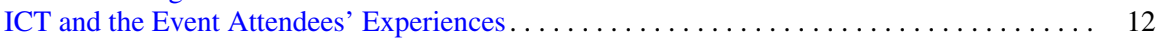

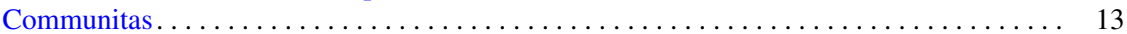

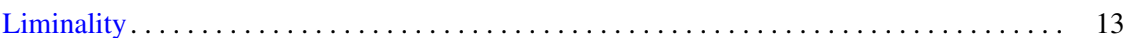

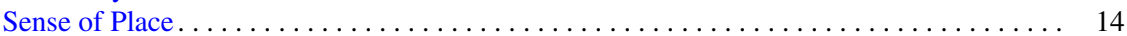

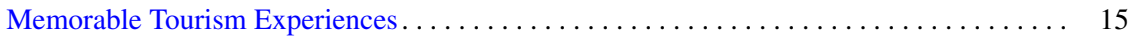

C. Van Winkle $(\triangle)$

Faculty of Kinesiology and Recreation Management, University of Manitoba, Winnipeg, MB, Canada

e-mail: Christine.vanwinkle@umanitoba.ca

\section{J. Bueddefeld}

Faculty of Kinesiology, Sport, and Recreation, University of Alberta, Edmonton, AB, Canada e-mail: Jill.Bueddefeld@umanitoba.ca 


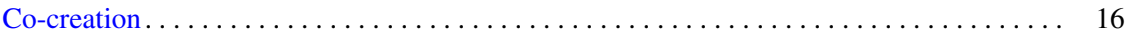

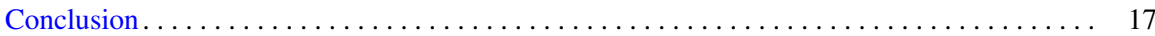

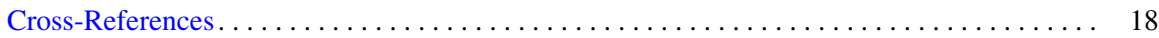

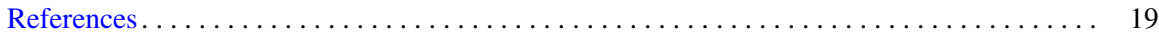

\section{Abstract}

This chapter provides a comprehensive overview of information and communication technologies (ICTs) used by event organizers and attendees. The ways that ICTs are integrated into event administration, design, operations, marketing, and risk management, both back-stage and in plain sight, are considered from an applied perspective and through the lenses of theories applied in the literature. Currently, events and festivals use diverse ICTs to enhance utilitarian aspects, such as ticket purchasing, safety procedures, wayfinding and scheduling, as well as hedonic visitor experiences, like virtual and enhanced reality, gamification, and innovative programming using social media. How ICTs influence attendees' experiences is discussed in-depth by exploring the contribution of ICTs to "communitas," "liminality," sense of place, mindfulness, memorableness, and co-creation. Throughout the chapter, both emerging and established ICTs are described, and real-world examples from festivals are provided to gain insights into the opportunities and drawbacks of ICTs in the event and festival domain. The chapter focuses on ICTs used during the festival experience. However, the importance of the pre- and post-event and festival experience is acknowledged as well.

\section{Keywords}

Festivals · Events · Information and communication technologies (ICTs) · Co-creation

\section{Introduction}

Events are considered a valued sector within the tourism industry. Thus, an increasing number of tourism destinations stage events to enhance destination image, attract visitors, and increase recreation opportunities for residents and tourists alike (Garay 2017). Festivals are events featuring a themed public celebration that brings residents and visitors together to share experiences (Getz 2007). The festival industry continues to grow, and before the 2020 Coronavirus pandemic projections estimated that the music festival industry alone would generate over \$20 billion in revenues through the early 2020s (FestForums 2017; Nielsen 2015). Studies from countries around the globe indicate that millions of people attend at least one festival per year (FestForums 2017; Nielsen 2015).

Although festivals have been part of cultural activity throughout history, the study of festival management and administration is relatively new (Getz 2010). Within the past 30 years, the events industry has become increasingly professionalized and 
discussed in the academic literature (ibid 2010). Within the same period, community celebrations have grown in complexity and number. As such, information and communication technology (ICT) has been increasingly integrated into festival management, in particular, to facilitate attendees' experience creation.

Nevertheless, festival management and administration is less researched than the domains of festival experience creation, impacts, and outcomes, respectively (Getz 2010). However, currently, this is a growing domain of academic study. A descriptive framework developed by (Silvers et al. 2005), known as the Event Management Body of Knowledge (EMBOK), provides a basic framework for considering the range of critical activities undertaken by event organizers. This framework that conceptualizes event management and administration is divided into five major knowledge domains: administration, design, marketing, operations, and risk (ibid 2003).

The purpose of this chapter is to explore how information and communication technologies (ICTs) are integrated throughout the EMBOK and, particularly, examines the implications for event attendees' experiences. The discussion focuses on technologies unique to events and to festivals in particular. Thus, both utilitarian and hedonic applications of ITCs within administration, design, marketing, operations, and risk management are considered. However, Getz (2010) notes that the five knowledge domains described by the EMBOK framework offer a limited view of festivals, as the focus is on practitioner skills rather than festival experiences and meanings. To address this drawback, the chapter also explores how ICTs are adopted and used beyond the EMBOK domains, in particular by highlighting ICTs' capacities to enhance the attendee's experience quality.

\section{Information and Communication Technologies and the Domains of Event Management}

\section{Administration Domain}

The administration domain includes all major administrative functions necessary to ensure the success of events, including financial and human resources as well as systems in place to facilitate the creation of attendees' experience (Silvers et al. 2005). As noted in the literature, ICTs have been used in the event context in particular for utilitarian purposes, such as online ticketing, entrance and site access, as well as wayfinding (Luxford and Dickinson 2015; Pasanen and Konu 2016; Peltonen et al. 2007).

\section{Secure Mobile and RFID Ticketing}

Within the past 10 years, mobile ticketing and cashless festival experiences have been implemented by the use of both radio frequency identification (RFID) tags and integrated wristbands (Hudson and Hudson 2013; Patchen 2015). These technologies have allowed for improved access to events and festivals, thereby helping 
administrators to reduce fraud, waiting-times at gates, and to ensure a seamless visitor experience (Hudson and Hudson 2013)

RFID wristbands were first used for entrance management at festivals and events, and eventually this technology evolved to incorporate secure virtual payments as well as the ability to connect with the various social media channels to share visitors' festival experience virtually (ibid 2013).

\section{Secure Virtual Payment Methods}

RFID technology has evolved quickly and RFID wristbands are linked to credit cards or loaded with funds on-site to allow festival attendees to pay for food, drinks, and merchandise. This, in turn, reduced waiting-times lost or stolen credit cards and the general need for cash on-site. For instance, Lollapalooza is credited with being one of the first music festivals in North America to integrate this technology the "Lolla" cashless RFID system (Patchen 2015). Lollapalooza's cashless system accounted for approximately one-third of total revenue, and, interestingly, the introduction of the technology is responsible for a $20 \%$ increase in attendees' spending (Patchen 2015). It is not known, however, whether this increase in spending was solely due to an increase in efficiency of payment processing, reduced waiting-times, or other causes. Regardless, the union of RFID technology with virtual payment capabilities increased overall revenues of festivals and, at the same time, enhanced attendees' experience quality (ibid 2015).

While RFID technology allows for faster and easier transactions, it is not without flaws. For instance, SZIGET festival visitors in Budapest have used a cashless system since 2011 and used RFID bracelets integrated with the "Festipay App" to pay for food and drinks on-site (SZIGET Festival 2019). While unspent funds added to the "Festipay App" were automatically refunded after 14 days, funds uploaded on-site at so-called "top-up points" were not automatically refunded (ibid 2019). Later, refunds had to be requested on-site at the "top-up points" during festival hours or by noon the next day. This process was problematic as attendees needed to be aware of multiple policies and capable of finding the top-up points locations onsite during the festival late at night or by noon the next day. At the end of a festival, attendees are keen to leave the venue quickly and may be too exhausted or inebriated to request a refund. Also, returning to the festival site the next day to redeem their wristband money is not feasible for many attendees. Thus, when using alternative forms of payment, festival organizers need to be cognizant of communicating refund information to attendees and of providing better ways through which funds can be redeemed automatically already during the festival or off-site after the festival. 


\section{Blockchain}

Decentralized blockchain technology can increase connections in particular between festival musicians and attendees, through the creation of a platform that connects festival attendees without a gatekeeper, thus allowing artists to interact directly with their fans in a less regulated way (Hu et al. 2018). In fact, according to a panel of experts at SXSW 2018 music festival, decentralized blockchain technologies are considered the "next revolution" in the festival domain. Breaker (2018), a decentralized blockchain platform, is described as "a blockchain-powered entertainment platform built for artists and by artists" (ibid 2018). More precisely, blockchain technologies work through a user-generated verification process, which creates a secure audit trail of authentication (Nãsulea 2018). Our Music Festival, known as OMF, debuting in San Francisco in 2018, was the first festival to use a fully integrated blockchain technology, thereby reducing ticket prices and giving fans enhanced control and access to experience the festival and its rewards (https:// www.youtube.com/watch?v=ArdaSzneVwA).

Blockchain technologies have the capacity to revolutionize the way festivals and events facilitate experiences. This technology has mainly facilitated "smart contracts," thereby automating payments that eliminate the need for third parties. In fact, these tools show the capacity to reduce administrative and organization costs as well as to increase trust (Hu et al. 2018).

\section{Design Domain}

Designing events involves integrating a theme, designing a program, altering the environment, and providing entertainment. According to Brown and Hutton (2013), a well-designed event provides effective communication to deliver the best experience to visitors possible:

The three pillars of the event design approach (an audience-centric approach) are [...]: to capture and engage the audience; to maximize the effectiveness of communication with the audience; to provide the foundation for the delivery of an optimal or peak experience for the audience; and, in doing so, to increase the potential for the event to meet and exceed its stated aims and objectives (ibid 2013, p. 44).

With the ubiquity of ICTs in people's daily lives, event organizers increasingly look for creative ways to engage their audience on-site through experience design. Events with unique design elements that use integrated ICTs are among of the most well known worldwide (Perez 2013). Festivals that offer a dynamic environment and incorporate interactive elements are consistently at the top of must-see festival lists (Holborow and Rogers 2019). 


\section{Festivalscape}

The term "festivalscape" refers to "the general atmosphere experienced by festival patrons" (Lee et al. 2008, p. 57). Research conducted by Lee et al. (2008) found that all the atmospheric aspects of the festivalscape contribute to satisfaction and, thus, to visitors' loyalty to the festival (Mason and Paggiaro 2012). When ICTs are used to design the festivalscape, organizers need to consider the implications for the attendee's experience. Examples of ICT design elements transforming the festivalscape include the use of video boards or social walls to project social media posts in real time, where attendees can see Instagram photos, videos, or Tweets from other attendees at the event in real time (Breaker 2018).

[Insert Video link: https://www.youtube.com/watch?v=verSA12Q-S8]

RFID bracelets have evolved from functional to interactive where they light up during particular songs. For instance, the band Coldplay designed their performance to incorporate RFID bracelets that light up in different colors to the rhythm of the music played (NME 2012). The band joked that they were nearly "going broke" because of the high cost of the wristbands, but they considered them to be integral to the aesthetic experience (NME 2012). Similarly, Day for Night Festival, Texas, incorporates technology-driven light-based art installations for creating a multisensory dance floor experience (Fig. 1):

The visual artists build experiences within the blurred boundaries of performance, interaction and immersive installations both indoors and out. Largescale projections and sitespecific custom-built structures bring a heightened sensorial experience to new audiences (Day for Night 2019)

Given the perceived value of creating a unique and integrated attendee experience, the above-described technologies will increasingly be integrated into future event experiences, as costs become less of a barrier (Perez 2013; Holborow and Rogers 2019).

Fig. 1 RFID festival wristbands that incorporate illuminating technology to add to the aesthetic experience. (Photo courtesy of Ryan on Unsplash)

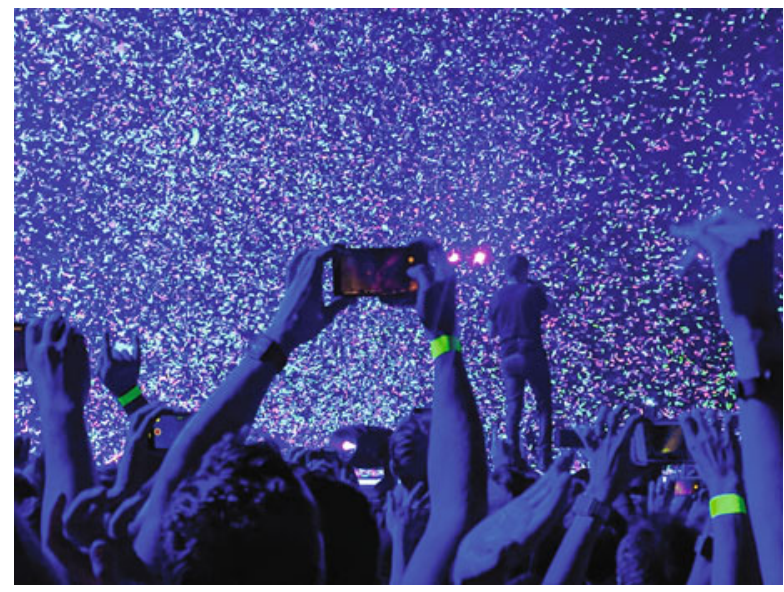




\section{Livestreaming}

The way that people experience festivals transcends space and time through livestreaming, social media, and artificial/enhanced and virtual reality experiences (Breaker 2018; Robertson et al. 2015). Coachella has streamed the festival's opening weekend since 2011. In 2019, the festival made the controversial decision to livestream both weekends on YouTube thus to provide unprecedented access via Snapchat stories, thereby creating an online festivalscape for fans not able to attend in person (Patchen 2015). Three separate livestreamed events on YouTube allow fans to customize their online festival experience which included curated content such as mini-documentaries and artist commentary addressed to visitors not present in person at the festival (Shaffer 2019). In the past, many festivals avoided livestreaming events for fear of discouraging people from purchasing tickets and attending in person (Swallow 2013). However, ICT has changed how events engage off-site audiences, and festival organizers recognize the value that can be added to experiences by incorporating elements not available on-site (Shaffer 2019; Swallow 2013). Given the cancellations of events worldwide due to the COVID-19 virus, it is likely that livestreaming will be used more often in the future to provide alternative forms of attendee experiences when visiting in person is not feasible.

\section{Holographic Technology}

In 2006, the band The Gorillaz and Madonna made history at the Grammys with the first ever holographic performance at an event (Kaufman 2017). An animated version of The Gorillaz opened the set where first a hologram Madonna emerged onstage, sang and interacted with Gorillaz' band members, and then disappeared when the real Madonna appeared to perform her song "Hung Up" with the Gorillaz hologram (ibid 2017). Several hologram performances at events followed this groundbreaking set. However, it was the performance of Tupac at Coachella that set a new bar for integrated holographic technology at festivals and events. Headlines read "Tupac returns from the dead at Coachella" (Guardian Music 2012), and this technology-enabled performance altered the way that special guests can engage with attendees without being neither physically present nor even alive.

Holographic technology emerged already in the 1960s and has been slowly evolving (Kucirkova 2018). However, only recently this technology has started to project three-dimensional holograms into a space. Like the Tupac appearance at Coachella, holographic performers are making their way on to stages at various music festivals and events to enhance visitors' experiences through interactive elements. Holographic technology has extended to non-humans, where Vocaloid Hatsune Miku, a computer-generated hologram created by Japanese designers performs for sold-out concerts in Tokyo, Singapore, Hong Kong, Taipei, and Los Angeles (Crypton Future Media 2019) (Fig. 2). 
Fig. 2 Holographic technology. (Photo courtesy of Danny Howe on Unsplash)

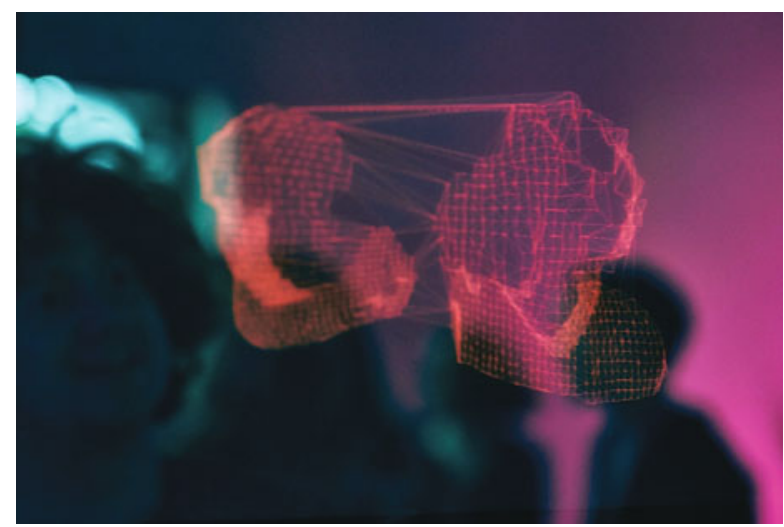

\section{Marketing Domain}

The marketing domain includes all of the functions required to develop and deliver a product to meet the needs of the target audience (Silvers et al. 2005). In the context of events, this includes promotion, public relations, sponsorship, and merchandising. ICT has significantly transformed the marketing domain where users act as co-producers by promoting events directly through their social media channels (Xiang and Gretzel 2010). In this context, events are able to gain support through online marketing where crowdfunding can be used to directly fund and support events (Freedman and Nutting 2015).

\section{Social Media}

Social media is typically used to market festivals and events (Xiang and Gretzel 2010; Harb et al. 2019). Social media marketing is particularly popular for festivals and events, which cater to a younger audience, thus who are more likely to use multiple social media channels and platforms regularly (Hudson and Hudson 2013).

Social media advertising continues to grow and predictions are that it will increase further and yield relatively stronger results because of its ability to tightly target audiences based on social media activity (ibid 2013, p. 207).

The same authors (ibid 2013) point out that consumers are engaging with brands differently but mainly in terms of contact points enabled through social media technologies. People spend more time researching brands and products through social media and, thus, "may remain aggressively engaged, actively promoting or assailing the products they have bought, and, thus, collaborating in the development of the brand" (Hudson and Hudson 2013, p. 207; see also: Crowther 2011). These activities alter the brand marketing plan, in that the final point of contact does not take place after the transaction but continues via social media as people share their experiences and reviews of their purchases (Hudson and Hudson 2013). For festivals 
and events, this continued engagement can help to curate a highly engaged yearround audience. However, research demonstrates that many event organizations do still not engage regularly on social media before or after their event or festival (MacKay et al. 2017).

\section{Crowdfunding}

Crowdsourced funding is a unique way to raise funds directly from the public to support an event financially. This funding tool emerged with the World Wide Web, and from the very beginning, it has particularly facilitated the funding of arts and cultural production (Freedman and Nutting 2015). Crowdfunding is typically based on rewards (i.e., people who pledge a minimum dollar receive an award for their pledge). However, many people donate small amounts of money without the promise of a reward, rather in order to see a product being developed. In a study designed to understand why organizations and individuals participate in crowdfunding researchers found that organizations use this tool not only to fundraise but also to receive validation, to build relationships, and to enhance awareness of the organization's work. In fact, while crowdfunding is useful for raising money, it also has broad product development and marketing appeal for organizations (Gerber 2012)

\section{Operations Domain}

Event operations include the management of both attendees, the site, technology, and the infrastructure, respectively (Silvers et al. 2005). Thus, ICTs are integrated into various operational elements such as waste and crowd management, which are each explored in detail next.

\section{Waste Management and Sustainability}

Events typically produce an enormous amount of waste and use a significant amount of resources in a relatively short period. Usually, events and festivals are hosted at locations such as fields or parks without a preexisting waste management infrastructure, thus making it difficult to manage waste and to reduce the impact on the physical site (Gray 2019). An average large-scale music festival in the USA is estimated to generate waste upward of 100 tonnes per day (ibid 2019). Thus, many festivals and events started focusing on environmental sustainability and trying to reduce their impact. For instance, DGTL Festival, Amsterdam, is attempting to become the first "circular-economy" or zero-waste festival in 2020 (DGTL 2019). By doing so, RFID technology is employed (Greenwalt 2017). More concretely, waste bins with RFID technology alert waste management staff when bins are full and need to be emptied. Moreover, new technology is emerging that can differentiate 
waste, types of recyclable, and compostable materials and to indicate where items should be placed. This capacity reduces the amount of janitorial staff and time spent on dealing with waste from improperly sorted bins. In addition to improving waste management, a recycling station on-site can become part of the on-site experience like in the case of DGTL Festival where a recycling hub shows attendees how their waste will be recycled and reused (DGTL 2019).

Recently, large event centers and in particular stadiums are employing the Internet of things (IoT), where devices of any kind are connected to the Internet and each other to create a more efficient on-site experience (McLaughlin 2018). IoT is defined as connecting powered objects to the internet or each other (Morgan 2014). So-called smart stadiums are using IoT to manage logistic aspects of the experience including parking, bathroom, and concession queues, respectively (ibid 2018).

\section{Crowd Management}

Managing crowds is most critical in order to ensure festival attendees have a positive experience and that their safety is maintained throughout the entire event. Thus, addressing queues and visitor flows is a key aspect of managing crowds, especially at large festivals and events (Van Winkle et al. 2014). Currently, smart venues integrate IoT technology to enhance their ability to manage large groups of people, such as smart lighting during an emergency (McLaughlin 2018). IoT is regularly used in combination with RFID to manage crowds and alert security staff about overcrowding or janitorial staff about the status of restroom facilities after a certain number of people have entered and exited a space (Yamin et al. 2018). The company Armored Things (https://www.armoredthings.com) uses machine learning to identify potential bottlenecks in event egress.

\section{Risk Domain}

This knowledge domain of event management includes emergency management, health and safety, as well as legal and security aspects, respectively (Silvers et al. 2005). ICTs are used by festival managers to reduce risk and enhance safety and security on-site. If implemented appropriately, technology offers a less invasive way for events to keep attendees safe compared with traditional security measures.

\section{Drone Surveillance}

Safety and security are of utmost importance for any festival or event. In the wake of the 2018 mass shooting at the Route 91 Harvest music festival, Las Vegas, security measures have increased worldwide, especially for major festivals (Winton 2018). 
Police in Indio, California, where Coachella takes place annually, utilize an army of drones to monitor the perimeter of the festival. The local police chief explained the benefits of using drones:

"Drones will be flying over watching the perimeters. It takes us a few minutes to get an officer to a perimeter breach but a drone takes 45 seconds [...] The drones will also allow us to monitor traffic better than before" (ibid 2018). In fact, in many instances, drones are more cost-effective than deploying additional officers on the ground and can more quickly arrive at an urgent situation (ibid 2018).

\section{RFID Tracking}

RFID wristbands are sometimes used in the event context to enhance safety and security (Yamin et al. 2018). RFID technology allows festival and event organizers to monitor the number of visitors inside the event as well as the flow of traffic outside the event. It was estimated that RFID technology reduced average entrance waiting-times for events from several hours to $30 \mathrm{~min}$ (Eventbrite 2019). Moreover, monitoring on-site visitor flows is enabled with "tap-in" technology. Here RFID readers are placed throughout the site and notify security personnel if there is a sudden influx of people in a particular area, such as a stage rush (TechWeekEurope 2015):

The RFID chips, usually in the form of tags, can be linked to a Wireless Sensor Network (WSN), cellular (3G/4G) network, or GPS (Yamin et al. 2018, p. 2).

RFID "passive tags" are most commonly used as they have a cost advantage, do not require batteries, and allow for only passive reading of the RFID information up to a 2 to 3 meter distance. In contrast, "active tags" allow for two-way communication. However, they are considerably more expensive (ibid 2018).

Event and festival organizations using RFID wristbands and tickets argue that an added benefit is the reduction of theft of tickets or cash. Interestingly, festival organizers also state that limiting cash on-site reduces illegal drug purchases (TechWeekEurope 2015). However, among the public, there are concerns regarding anonymity and access to private information with RFID technology. Nevertheless, RFID readers receive information only within 2 to 3 meters and can access only the information people have made available on RFID chips.

A further attractive feature of RFID technology is that it does not require WiFi to work, making it well suited for events and festivals, which often take place in fields or remote areas Intellitix, an RFID technology company that intensively works with festivals, states:

Our RFID platform eliminates ticket fraud, theft and loss of money, making it more secure than carrying cash or credit cards around a live event site. Unlike systems such as the Oyster Card [used for public transit], no cash or sensitive payment information is ever held on the actual wristband itself. If the wristband is lost or stolen, no money is at risk and the wristband can easily be deactivated and immediately replaced without losing any credit if it's been registered (Malivuk 2016). 
Data security depends upon data management systems and servers (ibid 2016). In the future organizations will need to be vigilant about changing security needs as the complexity of this is increasing with technological innovations.

\section{ICT and the Event Attendees' Experiences}

Within the tourism literature, it is recognized that ICTs play an important but conflicting role in mediating visitors' experiences (Gretzel 2011; Gretzel and Jamal 2009; Neuhofer et al. 2014). Research on technology acceptance and use examines the conditions under which visitors do and do not adopt and use technology in various contexts and settings (Bueddefeld et al. 2016; Pourfakhimi et al. 2019; Van Winkle et al. 2019).

The body of research exploring acceptance and use of ICTs in the festival context has been heavily informed by UTAUT2 evolved out of UTAUT, DIT, and TAM. The theoretical model indicates that performance expectancy, effort expectancy, social influence, facilitating conditions, hedonic motivation, habit, and price-value perception may affect behavioral intention to use ICTs (Venkatesh et al. 2012).

Van Winkle et al. (2019) examined the UTAUT2 through survey-based research at three festivals. The authors found that performance expectancy, hedonic motivation, habit, and age are among the main factors that significantly affect intention to use technology in the festival context (Van Winkle et al. 2019). However, it is widely acknowledged that behavioral intention does not fully reflect behavior (Van Winkle et al. 2019; Venkatesh et al. 2003; Williams et al. 2015). Nonetheless, this research highlights the factors that influence attendees' willingness to consider adopting ICTs in a festival context.

In an earlier study, Van Winkle et al. $(2014,2016)$ explored six festival cases and found that mobile device use can both enhance and detract from the on-site festival experience quality. More precisely, through a combination of on-site interviews with 154 festival attendees and observations the researchers found that device use enhances the festival experience when used to communicate with friends on-site, to organize the festival visit, and to enhance one's sense of safety. However, a number of attendees described how the use of a device hindered their enjoyment of the festival experience, particularly when they were using the device out of habit or when used for activities not related to the festival (ibid 2014; Bueddefeld et al. 2016). These findings informed subsequent research examining the Unified Theory of Acceptance and Use of Technology 2 (UTAUT2) in a festival context (Van Winkle et al. 2019).

In a similar vein of research, de Boer et al. (2012) discuss social media use during two music festivals. Their survey-based research explores pre-, post-, and during festival use of social media and the relationship between use and motivation. The authors conclude that the use of social media can distract from the experience but does not affect the overall satisfaction with the festival (de Boer et al. 2012).

According to Munar and Jacobsen (2014), understanding attendees' motivations and needs is essential when facilitating an experience that incorporates ICTs. 
Without considering these, organizers risk detracting from the on-site experience rather than enhancing it (Van Winkle et al. 2014; Van Winkle and Bueddefeld 2016).

\section{Communitas}

"Communitas" is a Latin term that describes unstructured communities, and when extended to festivals, it helps to depict the shared experience offered to attendees (Turner 1974a). The temporary state of togetherness formed by festivals is a unique feature of this leisure/tourism experience and has been discussed across major festival genres (Laing and Mair 2015). In fact, mobile connectivity shows the capacity to affect the communal experience at festivals. Research has repeatedly shown that festivals contribute to a sense of belonging and a sense of community (Hannam and Halewood 2006; Van Winkle et al. 2013). More precisely, Van Winkle et al. (2013) empirically tested the Brief Sense of Community Scale in a festival context. The authors found a strong relationship between the sense of emotional connection with others and attending a festival. Thus, when considering the role of ICT for enhancing social connections, social media engagement offers ways to create festival communities that exist beyond the limited time and space of the event itself.

Through survey research at three Canadian festivals, MacKay et al. $(2016,2019)$ examined how social media use before, during, and after a festival is affecting the engagement of the visitors. In total, 345 festival attendees completed an onsite survey upon their return home from the festival. Active social media use included writing posts, posting photos, commenting, and sharing, while passive use considered reading, following, viewing, and liking. Finally, customer engagement was measured using items adapted from to examine three engagement dimensions: affective, cognitive, and normative. Findings show that active and passive device use were associated with cognitive and affective engagement before, during and after the festival. A notable exception occurred during the festival, where no relation was found between active social media use and the engagement dimensions. Thus, the authors conclude that the ongoing passive use of social media to connect with the festival can contribute to engagement (ibid 2014). However, mobile device use that is unrelated to the festival (e.g., responding to work-related emails) negatively impact a attendee' experiences (MacKay et al. 2019).

\section{Liminality}

Liminoid is a term that describes the distinct place and time where festival and event experiences unfold (Getz 2007). "Liminality" was introduced by Turner (1974b) to convey the disorientation of time and space experienced during rites of passage. Recently, the concept has been adopted to describe the special space created for unique festival experiences (Lee et al. 2008; Shaffer 2019). Liminality has shown to 
be enhanced through design choices defining the context within which the festival exists.

As highlighted, holographic technology shows the potential to transform a site by adding virtual elements. Tupac's posthumous performance at Coachella is one of the best-known examples where holographic-like elements are integrated into a festival. Another recent application of this technology is in the design of festivalscapes. By adding grand objects and innovative imagery to the site, an alternate world may be created that enhances the liminal experience offered by the festival (Lee et al. 2008). This technology may also be used for utilitarian purposes like designating boundaries to guide people to a particular space within the festival area or marking important locations on-site without construction.

Similarly, the time boundaries of the festival can be expanded by ICTs as recordings become increasingly realistic and people can stream event elements after the event has ended (Shaffer 2019). In fact, with virtual reality (VR) technologies, the time and space of a festival experience is made available at any time or location potentially threatening the uniqueness of these festival experiences.

\section{Sense of Place}

While the liminal festival experience may be enhanced and expanded by virtual reality technology so might peoples' sense of place. Contemporary tourism research shows that destinations benefit from visitors gaining a distinct sense of place, which occurs when people develop a conceptual understanding of space and fill it with meaning (Relph 1976; Derrett 2003). In fact, event visitors develop a particularly strong sense of place, especially if they return to the event or festival repeatedly throughout their lifetime (ibid 2003).

Through VR it is possible for attendees to experience elements of a festival site outside of the festival environment, thus allowing them to virtually revisit a placebased experience and share it with others not physically present at the festival. Turner and Turner (2006) note that it is particularly important to consider what elements of place are appropriate for being recreated in virtual environments as they are generally less immersive than real placed ones.

Social media is offering festivals and events unique opportunities to shape people's sense of place by encouraging image sharing and the creation of online communities. More concretely, festivals and events use hashtags to help other visitors seeing images from their event and repost or share visitors' posts, stories, or tweets that align with the sense of place the event aims to engender (Garay 2017).

Finally, location-based technologies also show the capacity to enhance a sense of place (Farrelly 2012). Technology such as iBeacon pushes content to attendees' mobile devices when they are situated in a particular location. By sharing festival-related content on attendees' mobile devices at specific sites festivals engage attendees by providing need information like show cancellations or emergencies. 


\section{Memorable Tourism Experiences}

Festivals and events that create memorable on-site experiences enhance satisfaction and improve visitor loyalty (Tung and Ritchie 2011; Yoon et al. 2010; Van Winkle and Backman 2008). Mindfulness is an important aspect of the on-site experience that affects visitors' experience, and it has been explored in tourism research for the past 25 years (Moscardo 1992; Van Winkle and Backman 2008). Mindfulness is conceptualized as an attitude of mental openness that results in an adaptive and responsive state of mind (Frauman and Norman 2004; (Van Winkle and Backman 2008)). Limited research exists that explores mindfulness in festival and event settings. The limited research undertaken so far indicates that being mindful, or actively instead of passively engaged in one's environment, relates to attendees' satisfaction with their festival experience (Van Winkle and Backman 2008).

Recent research conducted by Van Winkle et al. (2018) demonstrates that visitors' who did not disconnect their mobile device during a festival (e.g., checking work emails) detracted from their experience rather than enhanced it. Thus, knowing how to enhance the on-site experience is integral when using ICTs that encourage visitors to be mindful and to create memorable experiences.

Getz (2012) notes that while a "wowfactor" or surprise element is important at festivals, there is also a need to create memorable experiences. Thus, research is needed to consider how ICTs can accomplish creating substantive experiences that include elements of surprise. Wearable devices and haptic technology may offer multisensory experiences that are both meaningful and novel (Robertson et al. 2015). For example, music festivalgoers wearing haptic shirts that change colors in response to music and rhythm potentially enhancing the festivalscape and the individual sensory experience (Scott 2010)

ICT has dramatically altered the way attendees curate and document their experiences. With RFID technology, attendees' wristbands synchronize to their social media accounts. Festivals such as Bonnaroo, Manchester, UK, and Coachella, California, USA, use this technology and create RFID "hubs" where festivalgoers can "check-in", post pictures, or upload tweets on twitter. Users create playlists linked directly to their Spotify (music application) account, featuring the musicians they saw perform at the festival (Hudson and Hudson 2013; TechWeekEurope 2015). In fact, Coachella uses exclusive playlists to encourage attendees to visit social media hub check-ins to curate a "digital postcard" called "My Coachella Story" sent to attendees after the event as a memento to be shared on social media (ibid 2015). Creating a digital postcard allows Coachella to connect with its audience after the on-site visit and provide it with a visual memory to share. While recalling the on-site visit is a crucial part of creating memorable tourism experiences, pre-made sharable social media is considered an excellent approach to online marketing and can be effective in curating memories (Hudson and Hudson 2013; Wang et al. 2012). 


\section{Co-creation}

Following Ramaswamy (2011) "co-creation is the process by which mutual value is expanded together, where value to participating individuals is a function of their experiences, both their engagement experiences on the platform and productive and meaningful human experiences that result" (ibid, p. 195). The concept of co-creation has been discussed within the marketing literature for over 20 years (Binkhorst and Dekker 2009). However, only recently, the theory is applied to conceptualize cocreation for understanding value added in practice (ibid 2011; Van Winkle et al. 2016). With the rise of the experience economy (Pine and Gilmore 1998), also events and festivals seek to improve how they facilitate co-created experiences for their attendees through ICTs (Crowther 2011).

Flinn and Frew (2014) highlight how co-creation is facilitated by technology and social media. As attendees capture and upload images, video, and reviews created, viewers gain a unique perspective, distinct from that of festival organizers. Flinn and Frew (2014) examined the Glastonbury Festival. They found that social media was essential for co-creating the festival experience and offered the festival enhanced opportunities to remain competitive and successful.

Similarly, Peltonen et al. (2007) study social media content created by users while visiting an event. The authors found that spectators enjoyed being able to share photos and particularly appreciated the tactile nature of using a multi-touch photo-sharing wall (ibid 2007). The authors describe this experience as "active spectatorship" considered as "a concept that refers to seeing spectator activity (spectating) of an event as engaging and interactive experience with lots of social interaction with other spectators" (ibid 2007 p. 131). This research supports the assumption that ICT-facilitated experiences enhance visitors' on-site experience by engaging an otherwise passive audience.

In particular, hologram technology and virtual performances show the capacity to enhance visitors' opportunities to co-create their event experiences. For example, the originator of the Vocaloid hologram performer, Hatsune Miku, has adopted a creative commons license for the original illustrations to facilitate co-creation. The inventor hopes to encourage the audience to engage creatively with Hatsune Miku content:

She [Hatsune Miku] is also often called a global icon or 'hub', because the culture around her encourages a worldwide creative community to produce and share Miku-related content. With the increase of remix works and the steadily growing global demands, Crypton Future Media, INC. engages consciously in the promotion, support and cultivation of the Hatsune Miku community (Crypton Future Media, INC)

Finally, gamification shows the capability both to support co-creative processes and to motivate and engage people (Liu et al. 2019). Many opportunities for co-creation involve game elements such as rules, goals, feedback, and voluntary participation during a "non-game experience" (ibid 2019). A gamified experience can include gamelike elements such as collectable points, competition, levels, and virtual and real rewards that often may take a digital form. In festival contexts, games are used to encourage people to attend certain venues, to specific perfor- 
mances, or to stop by at certain vendors. However, until today, only a few examples of festival gamification exist. Therefore, this direction will likely become integrated into festival applications through social media in the future (Yeoman 2013).

Recent research exploring visitor experiences and ICTs employed in festival and event contexts has predominantly focused on describing ICTs' use or on understanding both management's adoption and visitors' acceptance and use behavior, respectively (Ballantyne et al. 2014; Van Winkle et al. 2019, 2016). Given the diverse aspects of the festival and event experience directly or indirectly affected by the use of ICTs as highlighted throughout this chapter, more advanced theoretically guided research is needed for exploring and better understanding the evolving spectrum of ICT-enhanced experience in the event and festival domain

\section{Conclusion}

This chapter described how ICTs have been used in event management, with a specific focus on festivals. Events and festivals use ICTs to enhance both functional and hedonic elements of attendees' experience. In the event and festival domain, ICTs have been integrated for ticketing, safety monitoring, wayfinding, scheduling, virtual and enhanced reality, gamification, and on- and off-site programming through social media channels, respectively.

For the future, we expect that events and festivals will further increase the integration of ICTs like deregulated blockchain platforms and IoT (Robertson et al. 2015; Yeoman 2013). As visitors' expectations toward event experiences evolve and become more demanding, it is essential to consider how value co-creation can be supported effectively by ICT applications. Van Winkle et al. (2016) explored the festival experience from the attendees' perspective by conducting 55 interviews guided by personal meaning maps at performing arts festivals (Van Winkle and Falk 2015). The authors conclude that the attendees in tandem with event producers and influential others can add value to the festival experience. Findings were interpreted through the theoretical lens of service-dominant logic which suggests that "consumers are a key component in creating value, as value is not solely determined through the use of a good or service in one's life rather than through exchange" (ibid 2015, p. 240). Thus, the integration of technology to support the co-creation of event and festival experiences continues to be paramount.

While this chapter has focused on ICTs to enhance the attendees experience during the event, the pre- and post-festival stage has been widely ignored in both research and practice. However, ICTs offer many opportunities to expand the events' boundaries of time and space. In fact, in recent years major festivals and events have professionally recorded and broadly distributed the content of their events through various online channels. These experiences allow festivalgoers to relive and share their experience. At the same time, non-attendees can get a sample of the event and be driven to attend the event or festival in the future. While these pre- and postexperiences are currently offered as spectator opportunities, technology will further 
enhance the opportunities to engage virtually with the festival outside its boundaries of space and time.

There is an urgent need to consider ICT usage at events to address pressing social and ecological issues facing humanity. Data security privacy, surveillance society, environmental sustainability, abuse of power, and asymmetrical privilege should all be considered when exploring ICT at events. How technology can enhance security has been discussed in this chapter However, the introduction of drones, IoT objects, and blockchain technology in the event domain presents privacy challenges that have not been widely explored.

While many festivals have expended effort to enhance environmental sustainability at their events, commonly by reducing and managing waste, little thought has been given to minimizing the environmental impact of technology use at events. Rather, the environmental impact of using electronic devices is usually overlooked both in practice and in the event and e-tourism literature, respectively. Meanwhile, content-streaming and server access to use social media and blockchain technologies all have an environmental "cost" that is rarely considered (Seetharam et al. 2010).

Some authors argue that technology can create greater access by interrupting power structures (Minghetti and Buhalis 2010). However, this has not been clearly demonstrated in the event management literature. Thus, when integrating ICTs into festival management and for the enhancement of visitors' experience, it is crucial to consider digital haves and have nots.

Much of the literature exploring ICT at events appearing in the e-tourism literature has presented descriptive accounts when studying organizational and individual ICT use. More reliable explanatory models are needed to enhance our understanding and contribute to both theory and practice.

\section{Cross-References}

- A Futuristic View of Tourism in the Internet Ecosystem

- Applications of the Internet of Things and Ubiquitous Computing to the Tourism Domain

B Blockchain and Tourism

Development of ICT: From E-Tourism to Smart Tourism

- DMO's Use of Social Media for Marketing

$\checkmark$ Gamification

- IT-Based Tourism Experiences

- IT-Based Value Co-creation

- Sharing and Platform Economy in Tourism: An Ecosystem Review of Actors

- Smart Tourists and Intelligent Behaviour

- Social Media and Crisis Communication in Tourism and Hospitality

- Social Media Approaches and Communication Strategies in Tourism

- Strategic Use of IT in Tourism

- Value Co-creation in Dynamic Networks and E-Tourism 
- Virtual, Augmented and Mixed Reality in Tourism

- Virtual Reality and the End of Tourism

- When, What, How and Why Individual Travelers Utilize Social Media in Travel and Tourism

\section{References}

Ballantyne J, Ballantyne R, Packer J (2014) Designing and managing music festival experiences to enhance attendees' psychological and social benefits. Musicae Scientiae 18(1):65-83

Binkhorst E, Dekker TD (2009) Agenda for co-creation tourism experience research. J Hosp Mark Manag 18:311-327. https://doi.org/10.1080/19368620802594193

Bueddefeld J, Van Winkle C, Halpenny E, MacKay K (2016) Mobile device use and non-use in a festival context: the roles of age and gender. Travel and tourism research association Canada conference, Edmonton, Sept 2016

Breaker (2018) The 10 most tech-forward music festivals of 2018. https://medium.com/ singulardtv/the-10-most-tech-forward-music-festivals-of-2018-44a3189f33fe. Accessed 27 July 2019

Brown S, Hutton A (2013) Developments in the real-time evaluation of audience behaviour at planned events. Int J Event Festiv Manag 4:43-55. https://doi.org/10.1108/17582951311307502

Crowther P (2011) Marketing event outcomes: from tactical to strategic. Int J Event Festiv Manag 2:68-82. https://doi.org/10.1108/17582951111116623

Crypton Future Media (2019) Who is Hatsune Miku? https://ec.crypton.co.jp/pages/prod/vocaloid/ cv01_us. Accessed 27 July 2019

Day for Night (2019) About. https://dayfornight.io/about-day-for-night/. Accessed 27 July 2019

de Boer J, Brussee R, Rovers M, van Vliet H (2012) Social media and festival experience. In: ASCA international workshop 2012

Derrett R (2003) Festivals \& regional destinations: how festivals demonstrate a sense of community \& place. Rural Society. https://link-galegroup-com.uml.idm.oclc.org/apps/doc/A134388858/ HRCA?sid=lms. Accessed 31 July 2019

DGTL (2019) Sustainability. https://dgtl.nl/sustainability. Accessed 30 July 2019

Eventbrite (2019) Eventbrite extends platform with RFID technology to streamline entry management and cut wait times at large events and festivals. https://www.eventbrite. $\mathrm{ca} /$ pressreleases/eventbrite-extends-platform-with-rfid-technology-to-streamline-entry-manage ment-and-cut-wait-times-at-large-events-and-festivals/. Accessed 30 July 2019

Farrelly G (2012) The role of location-based services in shaping sense of place. Proc Am Soc Inf Sci Technol 49(1):1-3

FestForums (2017) https://www.festforums.com/new-blog-1/2017/5/31/festatistics-festivals-bythe-numbers. Accessed 7 Mar 2019

Flinn J, Frew M (2014) Glastonbury: managing the mystification of festivity. Leis Stud 33:418433. https://doi.org/10.1080/02614367.2012.751121

Frauman E, Norman WC (2004) Mindfulness as a tool for managing visitors to tourism destinations. J Travel Res 42(4):381-389

Freedman DM, Nutting MR (2015) A brief history of crowdfunding including rewards, donation, debt and equity platforms in the USA. http//www.freedman-chicago.com/ec4i. History-ofCrowdfunding.pdf. Accessed 30 July 2019

Garay L, Soledad MP (2017) Understanding the creation of destination images through a festival's twitter conversation. Int J Event Festiv Manag 8(1):39-54. https://doi.org/10.1108/IJEFM-042016-0030

Gerber EM, Hui JS, Kuo PY (2012) Crowdfunding: why people are motivated to post and fund projects on crowdfunding platforms. In Proceedings of the international workshop on design, influence, and social technologies: techniques, impacts and ethics 2(11):10. Northwestern University, Evanston 
Getz D (2007) Event studies: theory, research and policy for planned events. Oxford, Elsevier

Getz D (2010) The nature and scope of festival studies. Int J Event Manag Res 5:1-47

Getz D (2012) Event studies: discourses and future directions. Event Manag 16(2):171-187

Gray R (2019) The people fighting the war on waste at music festivals. http://www.bbc.com/ culture/story/20190627-the-people-fighting-the-war-on-waste-at-music-festivals. Accessed 30 July 2019

Greenwalt M (2017) How RFID technology is evolving in the waste and recycling industry. https://www.waste360.com/fleets-technology/how-rfid-technology-evolving-waste-and-recycl ing-industry. Accessed 30 July 2019

Gretzel U, Jamal T (2009) Conceptualizing the creative tourist class: technology, mobility, and tourism experiences. Tour Anal 14(4):471-481

Guardian Music (2012) Tupac returns from the dead at Coachella: The Guardian. https://www. theguardian.com/music/musicblog/2012/apr/16/tupac-coachella. Accessed 27 July 2019

Harb A, Fowler D, Chang H, Blum SC, Alakaleek W (2019) Social media as a marketing tool for events. J Hosp Tour Technol 10(1):28-44

Holborow O, Rogers J (2019) The best festivals in the world for 2019. https://www.cntraveller. com/gallery/best-festivals-in-the-world. Accessed July 272019

$\mathrm{Hu}$ Y et al (2018) Blockchain-based smart contracts - applications and challenges. arXiv: 1810.04699 [cs]

Hudson S, Hudson R (2013) Engaging with consumers using social media: a case study of music festivals. Int J Event Festiv Manag 4:206-223

Kaufman G (2017) Tupac, Michael Jackson, Gorillaz \& more: a history of the musical hologram. https://www.billboard.com/articles/columns/pop/7717042/musical-hologramshistory-dead. Accessed 27 July 2019

Kucirkova A (2018) What can we expect from hologram technology in the future? https://www. nasdaq.com/article/what-can-we-expect-from-hologram-technology-in-the-future-cm 992373. Accessed 30 July 2019

Laing J, Mair J (2015) Music festivals and social inclusion-the festival organizers' perspective. Leis Sci 37(3):252-268

Lee YK, Lee CK, Lee SK et al (2008) Festivalscapes and patrons' emotions, satisfaction, and loyalty. J Bus Res 61(1):56-64

Liu C R, Wang Y C, Huang W S, Tang W C (2019) Festival gamification: conceptualization and scale development. Tour Manag 74:370-381

Luxford A, Dickinson JE (2015) The role of mobile applications in the consumer experience at music festivals. Event Manag 19:33-46. https://doi.org/10.3727/152599515X14229071392909

MacKay K, Van Winkle CM, Halpenny E, Barbe D (2016) Social media use in festival and daily life contexts. Paper presented at the travel and tourism research association of Canada conference, Edmonton, Sept 2016

MacKay K, Barbe D, Van Winkle CM, Halpenny E (2017) Social media activity in a festival context: temporal and content analysis. Int J Contemp Hosp Manag 29(2):669-689

MacKay K, Barbe D, Van Winkle CM, Halpenny E (2019) Active vs passive social media use, attendee engagement, and festival loyalty. In: Travel and tourism research association international conference, Melbourne, June 2019

Malivuk M (2016) Top ten myths busted for festivals and events. https://intellitix.com/hub/top-tenmyths-busted-for-festivals-events. Accessed 30 July 2019

Mason MC, Paggiaro A (2012) Investigating the role of festivalscape in culinary tourism: the case of food and wine events. Tour Manag 33:1329-1336. https://doi.org/10.1016/j.tourman.2011. 12.016

McLaughlin M (2018) How sports entertainment venues use IoT to make stadiums smarter. https://biztechmagazine.com/article/2018/05/how-sports-entertainment-venues-use-IoT-makestadiums-smarter. Accessed 30 July 2019

Minghetti V, Buhalis D (2010) Digital divide in tourism. J Travel Res 49(3):267-281

Moscardo GM (1992) A mindfulness/mindlessness model of the museum visitor experience. Unpublished doctoral dissertation, James Cook University, North Queensland 
Morgan J (2014) Simple explanation of the 'Internet of Things'. https://www.forbes.com/sites/ jacobmorgan/2014/05/13/simple-explanation-internet-things-that-anyone-can-understand/\#781 6e6511d09. Accessed 21 July 2019

Munar AM, Jacobsen J (2014) Motivations for sharing tourism experiences through social media. Tour Manag 43:46-54. https://doi.org/10.1016/j.tourman.2014.01.012

Nãsulea C, Mic SM (2018) Using blockchain as a platform for smart cities. J E-Technol 9(2):37

Neuhofer B, Buhalis D, Ladkin A (2014) A typology of technology-enhanced tourism experiences. Int J Tour Res 16:340-350. https://doi.org/10.1002/jtr.1958

Nielsen (2015) https://www.nielsen.com/ca/en/insights/article/2015/thats-the-ticket-music-festgoers-are-ready-for-summer-in-canada/. Accessed 7 Mar 2019

NME (2012) Coldplay's Chris Martin: 'Our flashing wristbands cost too much money'. https:// www.nme.com/news/music/coldplay-204-1283538. Accessed 27 July 2019

Pasanen K, Konu H (2016) Use of social media for new service development by Finnish Event and Festival Organizers. Event Manag 20:313-325. https://doi.org/10.3727/ 152599516 X14682560744550

Patchen T (2015) 5 music festivals that rock at creating mobile experiences. https://www.linkedin. com/pulse/5-music-festivals-rock-creating-mobile-experiences-taylor-patchen. Accessed July 272019

Peltonen P et al (2007) Extending large-scale event participation with user-created mobile media on a public display. In: Proceedings of the 6th international conference on mobile and ubiquitous multimedia, MUM 2007. ACM, New York, pp 131-138. https://doi.org/10.1145/1329469. 1329487

Perez A (2013) 23 world festivals you won't want to miss. https://www.buzzfeed.com/ashleyperez/ 23-world-festivals-you-wont-want-to-miss. Accessed 29 July 2019

Pine BJ, Gilmore JH (1998) Welcome to the experience economy. Harv Bus Rev 76(4):97-105

Pourfakhimi S, Duncan T, Coetzee W (2019) A critique of the progress of eTourism technology acceptance research: time for a hike? J Hosp Tour Techno 110(4):689-746

Ramaswamy V (2011) It's about human experiences... and beyond, to co-creation. Ind Mark Manag 40:195-196. https://doi.org/10.1016/j.indmarman.2010.06.030

Relph EC (1976) Place and placelessness. Research in planning and design 1. Pion, London

Robertson M, Yeoman I, Smith KA et al (2015) Technology, society, and visioning the future of music festivals. Event Manag 19:567-587. https://doi.org/10.3727/ $152599515 X 14465748774001$

Scott L (2010) Glastonbury festival in the future. https://metro.co.uk/2010/06/24/glastonburyfestival-in-the-future-415420/. Accessed 30 July 2019

Seetharam A, Somasundaram M, Towsley D, Kurose J, Shenoy P (2010) Shipping to streaming: is this shift green? In: Proceedings of the first ACM SIGCOMM workshop on green networking, pp 61-68

Shaffer C (2019) YouTube expands Coachella streaming: what to expect, how to watch. https:// www.rollingstone.com/music/music-news/youtube-coachella-streaming-features-weekends-820 927/. Accessed 27 July 2019

Silvers JR, Bowdin GA, O'Toole WJ, Nelson KB (2005) Towards an international event management body of knowledge (EMBOK). Event Manag 9(4):185-198

Swallow E (2013) Would you skip a concert if it was live-streamed? https://www.forbes.com/sites/ ericaswallow/2013/07/21/livestream-concerts/\#71cab5947b8c. Accessed 30 July 2019

SZIGET Festival (2019) Festival info: cashless payment at the festival. https://szigetfestival.com/ en/festival-info\#!/c196/cashless-payment-at-the-festival. Accessed 27 July 2019

TechWeekEurope (2015) Why festivals not using RFID technology really should. https://www. silicon.co.uk/networks/m2m/festivals-rfid-technology-182881. Accessed 30 July 2019

Tung VWS, Ritchie JRB (2011) Exploring the essence of memorable tourism experiences. Ann Tour Res 38:1367-1386. https://doi.org/10.1016/j.annals.2011.03.009

Turner V (1974a) Pilgrimage and communitas. Studia Missionalia 23(1):305-327

Turner V (1974b) Liminal to liminoid, in play, flow, and ritual: an essay in comparative symbology. Rice Inst Pamphlet-Rice Univ Stud 60(3):53-92 
Turner P, Turner S (2006) Place, sense of place, and presence. Presence: Teleop Virt Environ 15(2):204-217

Van Winkle CM, Backman K (2008) Examining visitor mindfulness at a cultural event. Event Manag 12(3-4):163-169

Van Winkle CM, Bueddefeld JN (2016) Service-dominant logic and the festival experience. Int J Event Festiv Manag 7(3):237-254

Van Winkle CM, Falk JH (2015) Personal meaning mapping at festivals: a useful tool for a challenging context. Event Manag 19(1):143-150

Van Winkle CM, Woosnam K, Mohammed AM (2013) Sense of community and festival attendance. Event Manag 17(2):155-163

Van Winkle CM, Halpenny E, MacKay KJ (2014) Living on the edge: attending a festival without my mobile device. In: Abstracts of the travel and tourism research association international conference, Brugge, Sept 2014

Van Winkle CM, Cairns A, MacKay K, Halpenny E (2016) Mobile device use at festivals: opportunities for value creation. Int J Event Festiv Manag 7(3):201-218

Van Winkle CM, Bueddefeld JN, Halpenny E, MacKay KJ (2019) The Unified Theory of Acceptance and Use of Technology 2: understanding mobile device use at festivals. Leis Stud 38(5):634-650

Venkatesh V, Morris M, Davis G, Davis F (2003) User acceptance of information technology: toward a unified view. MIS Q 27(3):425-478

Venkatesh V, Thong J, Xu X (2012) Consumer acceptance and use of information technology: extending the unified theory of acceptance and use of technology. MIS Q 36(1):157-178

Wang D, Park S, Fesenmaier DR (2012) The role of smartphones in mediating the touristic experience. J Travel Res 51:371-387. https://doi.org/10.1177/0047287511426341

Williams MD, Rana NP, Dwivedi YK (2015) The unified theory of acceptance and use of technology (UTAUT): a literature review. J Enterp Inf Manag 28(3):443-488

Winton R (2018) Coachella: police using army of drones to boost security in wake of Las Vegas massacre. https://www.latimes.com/local/lanow/la-me-coachella-security-drones-cops20180412-story.html. Accessed 30 July 2019

Xiang Z, Gretzel U (2010) Role of social media in online travel information search. Tour Manag 3:179-188. https://doi.org/10.1016/j.tourman.2009.02.016

Yamin M, Basahel AM, Abi Sen AA (2018) Managing crowds with wireless and mobile technologies. Wirel Commun Mob Comput 1-15. https://doi.org/10.1155/2018/7361597

Yeoman I (2013) A futurist's thoughts on consumer trends shaping future festivals and events. Int J Event Festiv Manag 4:249-260

Yoon YS, Lee JS, Lee CK (2010) Measuring festival quality and value affecting visitors' satisfaction and loyalty using a structural approach. Int J Hosp Manag 29(2):335-342 